medRxiv preprint doi: https://doi.org/10.1101/2020.07.17.20156141; this version posted July 17, 2020. The copyright holder for this preprint

(which was not certified by peer review) is the author/funder, who has granted medRxiv a license to display the preprint in perpetuity.

All rights reserved. No reuse allowed without permission.

\title{
Trends in demographic and clinical characteristics of patients enrolled in HIV care and subsequent Antiretroviral Therapy initiation in the Central Africa International epidemiology Database to Evaluate AIDS (CA-leDEA) Adult Cohort 2004-2018.
}

Adebola A. Adedimeji ${ }^{1}$, Donald R. Hoover ${ }^{2}$, Qiuhu Shi ${ }^{3}$, Hae-Young Kim³ ${ }^{3}$, Ellen Brazier ${ }^{4}$, Jonathan Ross ${ }^{5}$, Gad Murenzi ${ }^{6}$, Christella Twizere, Patricia Lelo ${ }^{8}$, Dominique Nsonde ${ }^{9}$, Rogers Ajeh ${ }^{10}$, Anastase Dzudie ${ }^{10}$,

Denis Nash ${ }^{4}$, Marcel Yotebieng ${ }^{5}$, Kathryn M. Anastos ${ }^{1},{ }^{5}$ for the Central Africa leDEA Consortium

${ }^{1}$ Department of Epidemiology and Population Health, Albert Einstein College of Medicine/Montefiore Medical Center, Bronx, NY

${ }^{2}$ Department of Statistics, Rutgers University, Piscataway, NJ

Corresponding author:

Adebola A. Adedimeji, Ph.D

${ }^{4}$ School of Public Health, City University of New York, New York, NY

${ }^{5}$ Division of General Internal Medicine, Montefiore Medical Center, Bronx, NY

${ }^{7}$ Centre National de Reference en Matière de VIH/SIDA, Burundi

${ }^{8}$ Pediatric Hospital Kalembe Lembe, Lingwala, Kinshasa, Democratic Republic of Congo

${ }^{9}$ CTA Brazzaville, Republic of Congo

${ }^{10} \mathrm{Clinical}$ Research Education, Networking and Consultancy, Yaounde, Cameroon 
medRxiv preprint doi: https://doi.org/10.1101/2020.07.17.20156141; this version posted July 17, 2020. The copyright holder for this preprint (which was not certified by peer review) is the author/funder, who has granted medRxiv a license to display the preprint in perpetuity.

All rights reserved. No reuse allowed without permission.

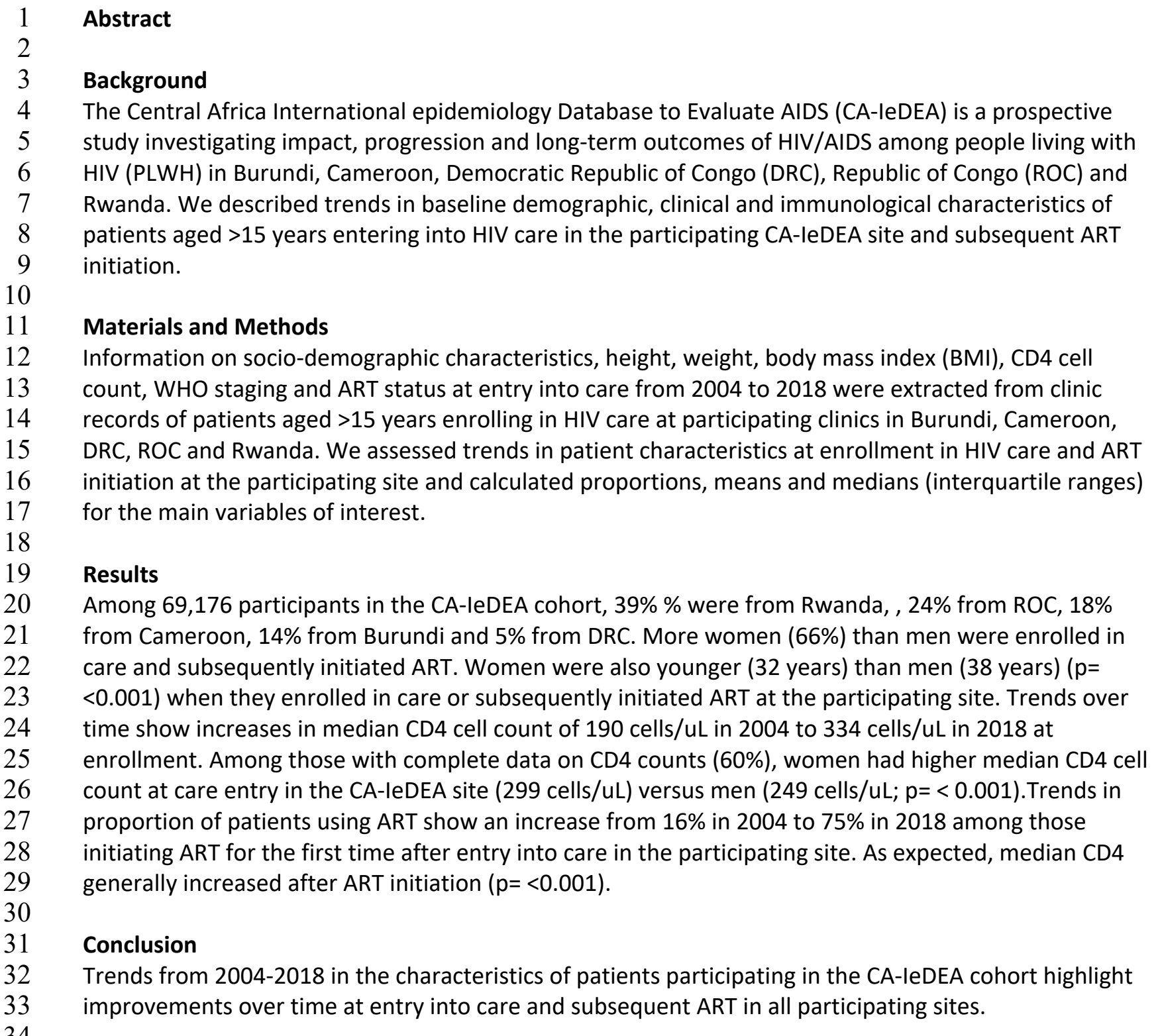


medRxiv preprint doi: https://doi.org/10.1101/2020.07.17.20156141; this version posted July 17, 2020. The copyright holder for this preprint (which was not certified by peer review) is the author/funder, who has granted medRxiv a license to display the preprint in perpetuity.

All rights reserved. No reuse allowed without permission.

\section{Introduction}

2 Globally, over 37.9 million people aged $>15$ years are living with HIV of whom 24.5 million were 3 estimated to be accessing antiretroviral therapy (ART). ${ }^{1}$ Expanded access to ART contributed to 4 improved quality of life and declines in AIDS-related mortality in people living with HIV (PLWH). To 5 consolidate these gains and end the threat of HIV to global public health, the Joint United Nations 6 Program on AIDS (UNAIDS) recommended the "90-90-90" strategy to ensure 90\% of PLWH are 7 diagnosed and know their status, $90 \%$ of those diagnosed are initiated on ART and $90 \%$ of those 8 initiating ART attain viral suppression. To facilitate the attainment of these global targets, the World 9 Health Organization (WHO) put out the "Treat All" guidelines, which recommended immediate ART 10 initiation for all persons diagnosed with HIV regardless of CD4 or viral load. ${ }^{2}$

Despite expanded ART access, sub-Saharan Africa (SSA) is still disproportionately burdened by HIV. For

13 instance in $2018,73 \%$ of all new HIV infections diagnosed globally were in the region. ${ }^{3}$ In most of SSA,

14 progress towards the 90-90-90 targets is uneven with many countries in East and Southern Africa 15 making remarkable progress compared with those in West and Central Africa. ${ }^{4,5}$ Whereas, the 25 16 countries in West and Central Africa comprised only $6 \%$ of the world's population, they accounted for $1718 \%$ of global HIV burden. ${ }^{6}$ The UNAIDS estimated that 4.7 million people living with HIV in West and 18 Central Africa lack access to treatment, a sharp contrast with treatment coverage in East and Southern

19 Africa regions. ${ }^{6}$ These discrepancies led to a regional catch up plan to accelerate progress in West and

20 Central Africa, but this has not translated into meaningful gains in scaling up access for millions of PLWH 21 in the region. ${ }^{6}$

23 The lack of progress reflects disparities in access to care for many PLWH in Central Africa who continue 24 to experience late diagnosis, non-linkage to care and poor HIV outcomes. . $^{1,2,3,4,5,6,7}$ Social and structural 25 instability, especially stigma, weak health systems, civil unrest and other contextual factors impeded 26 access to HIV care and progress towards universal targets. ${ }^{5-8}$ To address gaps in access to care for PLWH 27 in Central Africa, it is critical to understand the characteristics of PLWH enrolling in care at given sites 28 and subsequently initiating ART. Additionally, knowledge of trends in demographic, immunological and 29 clinical characteristics among PLWH enrolled in care can highlight challenges in implementing effective 30 strategies to facilitate early diagnosis and linkage to care for PLWH in these countries. 
medRxiv preprint doi: https://doi.org/10.1101/2020.07.17.20156141; this version posted July 17, 2020. The copyright holder for this preprint (which was not certified by peer review) is the author/funder, who has granted medRxiv a license to display the preprint in perpetuity.

All rights reserved. No reuse allowed without permission.

1 The Central Africa International epidemiology Database to Evaluate AIDS (CA-IeDEA) research

2 consortium was established with funding from the United States National Institutes of Health to be a

3 resource to investigate the impact, progression and long-term outcomes of the HIV/AIDS epidemic in

4 Central Africa and answer epidemiologic research questions that cannot be answered by separate

5 individual cohorts. The CA-leDEA routinely collects socio-demographic, clinical and immunologic data

6 from patients enrolled in HIV care at participating treatment sites in Burundi, Cameroon, Democratic

7 Republic of Congo, Republic of Congo and Rwanda. These data provide insights on trends in

8 sociodemographic, clinical and immunological characteristics of adult patients entering HIV care in the

9 given site and subsequently initiating ART in the participating countries. The objective of this study was

10 to examine these trends in sociodemographic, clinical and immunological characteristics of adult

11 patients aged $>15$ years entering care in the current site and subsequently initiating ART in CA-leDEA

12 regional cohort from 2004-2018 with the goal of describing trends in these characteristics over time.

14 Methods

Study Settings

16 The Central Africa leDEA (CA-leDEA) is one of the 7 regional cohorts within the global leDEA consortium

17 [https://www.iedea.org/], with other cohorts in East Africa, Southern Africa, West Africa, North

18 America, the Caribbean and Central/South America and Asia-Pacific regions. The overall leDEA cohort,

19 which has been previously described ${ }^{9}$ consists of 1.7 million PLWH of which 1.4 million in SSA are on

20 ART.

22 The CA-leDEA cohort currently comprises 19 active sites in Burundi, Cameroon, Democratic Republic of 23 Congo (DRC), Republic of Congo (ROC), and Rwanda, and one historical site in DRC that contributed

24 patient data to the cohort until mid 2013. The 19 active sites are predominantly public sector health

25 facilities, including tertiary-level university teaching hospitals and primary level health centers. All the

26 sites are located in urban or peri-urban settings. Details of CA-leDEA sites have been previously

27 described. ${ }^{9}$ Patients ever enrolling in HIV care at these participating sites are prospectively included in

28 the CA-leDEA cohort. Data from routine patient care are regularly extracted from patient records and

29 electronic medical records and harmonized into a regional dataset for use in country-level and regional

30 analyses. As of July 2018, there were approximately 70,000 patients in the CA-leDEA database. 
medRxiv preprint doi: https://doi.org/10.1101/2020.07.17.20156141; this version posted July 17, 2020. The copyright holder for this preprint (which was not certified by peer review) is the author/funder, who has granted medRxiv a license to display the preprint in perpetuity.

All rights reserved. No reuse allowed without permission.

Study Design and population

2 This analysis included all adult patients aged $>15$ years enrolled for HIV care in the CA-leDEA cohort at participating sites in Burundi, Cameroon, Democratic Republic of Congo, Republic of Congo and Rwanda. Data obtained during routine patient care in each country are extracted from an electronic data collection and storage system in each country, for example, the Open Medical Records System (in

6 Rwanda), SANTIA (in ROC), SIDA (in Burundi) and RedCap (in Cameroon and DRC) ${ }^{10}$ as mandated by the local health authority in each country. These data are then uploaded to a central data server at the CAleDEA data center in New York where they undergo cleaning and harmonization prior to analysis.

Ethical Approval

11 Ethical approval for the study was granted by the Albert Einstein College of Medicine Institutional

12 Review Board in New York, and the relevant ethics review boards in Rwanda (Rwanda National Health

13 Research Committee and the National Ethics Committee), Burundi (Comite National d'Ethique),

14 Cameroon (Comite National D'Ethique la Recherche en la Sante Humaine- CNERSH) DRC (Ministere de 15 I'Enseignement Superieur et Universitaire, University de Kinshasa Ecole de Sante Publique) and in the 16 Republic of Congo (Comite d'Ethique De La Recherche En Sciences De La Sante (CERRSSA). Data for the 17 Central Africa International Epidemiology to Evaluate AIDS (CA-IeDEA) is available upon request.

\section{Measures}

20 The following socio-demographic characteristics were assessed at entry into care at the participating CA-

21 leDEA site: age, gender, and marital status, reported pregnancy among women and route of entry into

22 HIV care in the participating site such as voluntary counseling and testing (VCT), prevention of mother-

23 to-child transmission (PMTCT), Tuberculosis (TB) clinic or In-patient care. Clinical and immunological

24 characteristics assessed at entry into HIV care at the participating CA-leDEA site included weight, height,

25 BMI, CD4 cell count, WHO stage at enrollment and ART usage. ART usage prior to enrollment was

26 defined as ART use $>30$ days before entering care in the participating site. ART use immediately after

27 entering HIV care at the participating site was defined as ART initiation starting $<=30$ days before

28 enrollment to 30 days after enrollment. We considered CD4 cell count measures at enrollment defined

29 as the closest CD4 measure available at enrollment date up to 3 months and 30 days prior to enrollment

30 date. CD4 cell count measure at ART initiation was defined as first CD4 measure available 30 days and up

31 to 3 months after ART initiation date among patients who initiated ART use after enrollment. 
medRxiv preprint doi: https://doi.org/10.1101/2020.07.17.20156141; this version posted July 17, 2020. The copyright holder for this preprint (which was not certified by peer review) is the author/funder, who has granted medRxiv a license to display the preprint in perpetuity.

All rights reserved. No reuse allowed without permission.

Statistical Analysis

2 For this analysis, we calculated proportions, means (standard deviations) and medians (interquartile

ranges) for the main variables of interest. We ultimately categorized all continuous variables as shown in the Tables and used Chi-Square tests to make comparison of all variables between groups. We also calculated the same data summaries by calendar year of enrollment into HIV care at the CA-IeDEA participating site and by country.

\section{Results}

Table 1 presents the socio-demographic and clinical profile of 69,176 patients entering HIV care in the

11 CA-IeDEA cohort in all the five participating countries. The largest proportion of patients (39\%) was in

12 Rwanda and the smallest proportion (5\%) was in the DRC. There were almost twice as many women

$13(66 \%)$ as men enrolled in the participating sites. Most patients reported being married (28\%) or single

14 (23\%). The median age at enrollment in the participating CA-leDEA sites was 35 years (IQR: 28,42).

15 Women were generally younger (33 years; IQR: 27,40$)$ than men (38 years; IQR: 32,45$)$ at enrollment in

16 the participating clinics. The largest proportion of patients enrolled in HIV care at the participating site

17 through voluntary counseling and testing (VCT) clinics (31\%) and prevention of mother-to-child (PMTCT)

18 clinics (9\%).

20 The median weight, height and BMI for patients at entry into HIV care at participating clinics was $57 \mathrm{~kg}$

21 (IQR: 50,65); 163cm (IQR: 158,169) and $21.63 \mathrm{~kg} / \mathrm{m}^{2}$ (IQR:19.27,24.38) respectively. Median CD4 at entry

22 into care at the participating site was 282 cells/uL (IQR:139, 476) among those for whom the CD4 cell

23 count measure was available. Women enrolled in care at the participating site with higher CD4 count

24 (299 cells/uL, IQR: 151, 501) than men (249 cells/uL; IQR: 119, 427). About half of patients (49.9\%)

25 enrolled in care with WHO Stage I or Stage II disease. Slightly higher proportion of men (24\%) enrolled in

26 care with advanced HIV disease (WHO Stage III and Stage IV) than women (20\%).

About $46 \%$ of patients who enrolled in care at the participating sites did not use any antiretroviral

29 therapy (ART) up to 3 months post enrollment; $11 \%$ initiated ART prior to (> 30 days) enrollment in HIV

30 care at the participating site, and $42 \%$ initiated ART immediately after enrollment in HIV care at the

31 participating site. The proportions of those who initiated ART before enrollment in HIV care and after

32 enrollment at the participating sites were similar among men and women. 
medRxiv preprint doi: https://doi.org/10.1101/2020.07.17.20156141; this version posted July 17, 2020. The copyright holder for this preprint (which was not certified by peer review) is the author/funder, who has granted medRxiv a license to display the preprint in perpetuity.

All rights reserved. No reuse allowed without permission.

1 Table 1: Demographic and clinical characteristics of all adult patients at enrollment into care by sex

\begin{tabular}{|c|c|c|c|c|c|}
\hline Variable & Code & Total & Women & Men & P-value \\
\hline Adult & & 69176 & $45933(66.4)$ & $23243(33.6)$ & \\
\hline Pregnant & & & $2869(6.2)$ & & \\
\hline \multirow[t]{5}{*}{ Age (yrs) median (IRQ) } & Median (IQR) & $35(28,42)$ & $33(27,40)$ & $38(32,45)$ & $<0.001$ \\
\hline & $15-24$ & 8894 (12.9) & 7291 (15.9) & $1603(6.9)$ & $<0.001$ \\
\hline & $25-34$ & $25623(37.0)$ & $19088(41.6)$ & $6535(28.1)$ & \\
\hline & $35-44$ & $22031(31.8)$ & $13113(28.5)$ & $8918(38.4)$ & \\
\hline & $45+$ & $12628(18.3)$ & $6441(14.0)$ & $6187(26.6)$ & \\
\hline \multirow[t]{6}{*}{ Point of entry into care } & PMTCT & $6530(9.4)$ & $5623(12.2)$ & $907(3.9)$ & $<0.001$ \\
\hline & TB & $38(0.1)$ & $27(0.1)$ & $11(0.0)$ & \\
\hline & VCT & $21285(30.8)$ & $12372(26.9)$ & $8913(38.3)$ & \\
\hline & Inpatient & $1009(1.5)$ & $524(1.1)$ & $485(2.1)$ & \\
\hline & Other & $6177(8.9)$ & $3904(8.5)$ & $2273(9.8)$ & \\
\hline & Unknown & $34137(49.3)$ & $23483(51.1)$ & $10654(45.8)$ & \\
\hline \multirow[t]{6}{*}{ Marital status } & Single & $15894(23.0)$ & $10911(23.8)$ & $4983(21.4)$ & $<0.001$ \\
\hline & Married/in union & $19345(28.0)$ & $10735(23.4)$ & $8610(37.0)$ & \\
\hline & Living with partner & 3413 (4.9) & $2372(5.2)$ & $1041(4.5)$ & \\
\hline & Divorced & $3153(4.6)$ & $2326(5.1)$ & $827(3.6)$ & \\
\hline & Widowed & $5073(7.3)$ & $4299(9.4)$ & $774(3.3)$ & \\
\hline & Unknow/Missing & $22298(32.2)$ & $15290(33.3)$ & $7008(30.2)$ & \\
\hline \multirow[t]{2}{*}{ Weight for adults, Kg } & Median (IQR) & $57(50,65)$ & $56(49,64)$ & $59(53,67)$ & $<0.001$ \\
\hline & Missing n (\%) & 20702(29.9) & $13901(30.3)$ & $6801(29.3)$ & \\
\hline \multirow[t]{2}{*}{ Height for adults, $\mathrm{Cm}$} & Median (IQR) & $163(158,169)$ & $160(155,165)$ & $170(165,175)$ & $<0.001$ \\
\hline & Missing n (\%) & 20555(29.7) & 13551(29.5) & 7004(30.1) & \\
\hline \multirow[t]{2}{*}{ BMI } & Median (IQR) & $21.63(19.27,24.38)$ & $22.07(19.53,24.98)$ & $20.94(18.93,23.31)$ & $<0.001$ \\
\hline & Missing n (\%) & $31156(45.0)$ & $20702(45.1)$ & $10454(45.0)$ & \\
\hline \multirow[t]{6}{*}{ CD4 count (cells/uL) } & Median (IQR) & $282(139,476)$ & $299(151,501)$ & $249(119,427)$ & $<0.001$ \\
\hline & $<100$ & 7500 (10.8) & $4610(10.0)$ & $2890(12.4)$ & $<0.001$ \\
\hline & 100-199 & 7513 (10.9) & $4846(10.6)$ & $2667(11.5)$ & \\
\hline & $200-349$ & $10093(14.6)$ & $6739(14.7)$ & $3354(14.4)$ & \\
\hline & $>350$ & $16456(23.8)$ & $11811(25.7)$ & $4645(20.0)$ & \\
\hline & Missing n (\%) & 27614 (39.9) & $17927(39.0)$ & $9687(41.7)$ & \\
\hline \multirow[t]{5}{*}{$\begin{array}{l}\text { WHO Stage at } \\
\text { enrollment }\end{array}$} & Stage I & $21004(30.4)$ & $14247(31.0)$ & $6757(29.1)$ & $<0.001$ \\
\hline & Stage II & $12961(18.7)$ & 8659 (18.9) & $4302(18.5)$ & \\
\hline & Stage III & $11167(16.1)$ & $6967(15.2)$ & $4200(18.1)$ & \\
\hline & Stage IV & $3698(5.3)$ & 2257 (4.9) & $1441(6.2)$ & \\
\hline & Missing n (\%) & $20346(29.4)$ & $13803(30.1)$ & $6543(28.2)$ & \\
\hline \multirow[t]{5}{*}{ Country } & Rwanda & $26930(38.9)$ & $16651(36.3)$ & $10279(44.2)$ & $<0.001$ \\
\hline & Burundi & $9720(14.1)$ & 6409 (14.0) & 3311 (14.2) & \\
\hline & Cameroon & $12482(18.0)$ & $8323(18.1)$ & 4159 (17.9) & \\
\hline & DRC & $3292(4.8)$ & $2718(5.9)$ & $574(2.5)$ & \\
\hline & ROC & $16752(24.2)$ & $11832(25.8)$ & $4920(21.2)$ & \\
\hline \multirow[t]{4}{*}{ Time Period } & Year $<=2006$ & $15054(21.8)$ & $10246(22.3)$ & $4808(20.7)$ & $<0.001$ \\
\hline & Year 2007 - 2010 & $17488(25.3)$ & $11717(25.5)$ & $5771(24.8)$ & \\
\hline & Year 2011 - 2014 & $17761(25.7)$ & $12125(26.4)$ & $5636(24.2)$ & \\
\hline & Year >= 2015 & $18873(27.3)$ & $11845(25.8)$ & $7028(30.2)$ & \\
\hline
\end{tabular}


medRxiv preprint doi: https://doi.org/10.1101/2020.07.17.20156141; this version posted July 17, 2020. The copyright holder for this preprint (which was not certified by peer review) is the author/funder, who has granted medRxiv a license to display the preprint in perpetuity.

All rights reserved. No reuse allowed without permission.

\begin{tabular}{|l|l|c|c|c|c|}
\hline & Not on ART & $32233(46.6)$ & $21357(46.5)$ & $10876(46.8)$ & $<0.001$ \\
\cline { 2 - 6 } & Before enrollment* & $7601(11.0)$ & $5268(11.5)$ & $2333(10.0)$ & \\
\cline { 2 - 6 } $\begin{array}{l}\text { ART Status at } \\
\text { enrollment }\end{array}$ & $\begin{array}{l}\text { Immediately after } \\
\text { enrollment** }\end{array}$ & $29342(42.4)$ & $19308(42.0)$ & $10034(43.2)$ & \\
\hline
\end{tabular}

*: >30 days prior to enrollment day, ${ }^{* *}$ within 30 days after enrollment day $\quad{ }^{1}$ By Chi-Square Tests

Trends in measures of body mass index, CD4 cell count, and WHO stage at enrollment into care in all participating clinics

Figure 1 show calendar year trends in having a recent measure of body mass index (BMI), CD4 cell count and WHO staging at enrollment in the participating CA-leDEA site for patients in all participating countries and separately for each country. Overall, there was a steady increase in the proportion of patients with measures of BMI from 2004 to up to the period after 2017. There was a similar gradual increase in the proportion of patients with WHO staging from 2004-2007 before a gradual decrease from 2008 and a leveling off at 78\% after 2017. A similar pattern emerged regarding availability of measures of CD4 cell count, which increased in all years, except in 2010 and 2014 when there were slight decreases and then a sharp decline in the period after 2017.

Fig. 1: Trends measures of BMI, CD4 cell count and WHO stage at enrollment in all countries participating in the CA-leDEA cohort

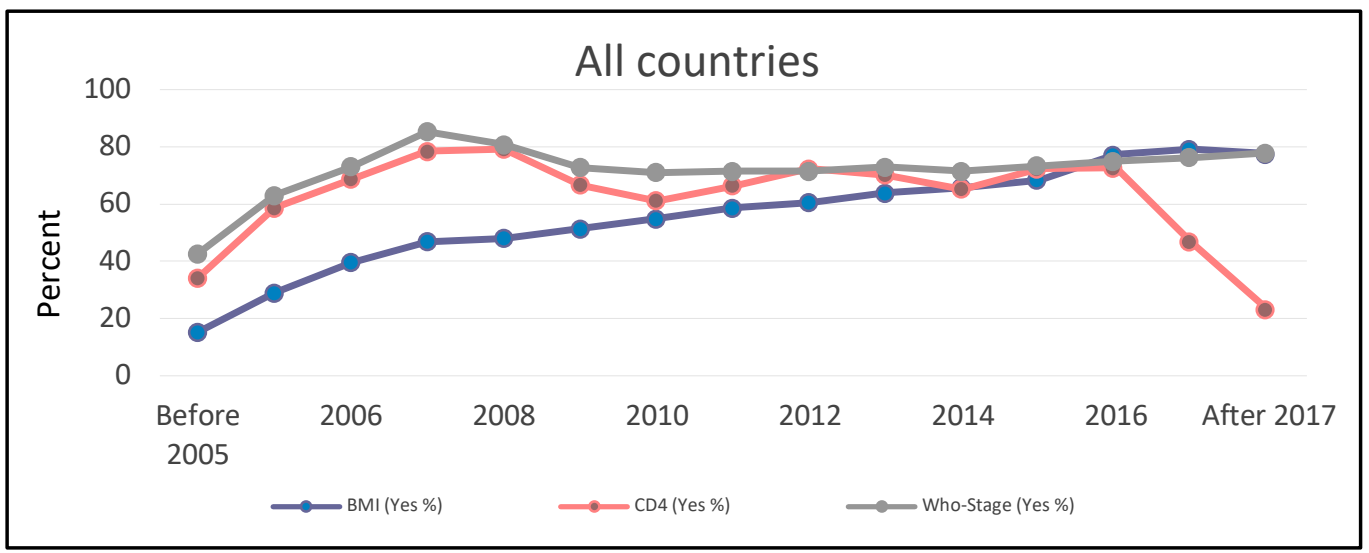

Disaggregated data of trends in measures of BMI, CD4 cell count and WHO staging by calendar years in each participating country are shown in supplementary figures S1-S5.

Starting with Burundi (Figure S1) where measures were only available to this study from 2009 on the proportion of patients with BMI and WHO Stage measures increased between 2009 and 2014 before a sharp decline for BMI and leveling off for WHO stage between 2015 and 2017, and slight decline in the period after 2017. Trends in available CD4 cell count measures were declined from 2009 and 2015, rose 
medRxiv preprint doi: https://doi.org/10.1101/2020.07.17.20156141; this version posted July 17, 2020. The copyright holder for this preprint (which was not certified by peer review) is the author/funder, who has granted medRxiv a license to display the preprint in perpetuity.

All rights reserved. No reuse allowed without permission.

1 slightly in 2016 when the Treat All guidelines ended the CD4 eligibility criterion for ART and thus

2 declined again from 2017 on. In Cameroon (Figure S2) trends in measures of BMI show a gradual

3 increase in the proportion of patients with this measure from 2004-2008, a gradual decrease until 2015

4 before a sharp increase since 2016. Trends in proportion of patients with measures of CD4 fluctuated

5 between 2004 and 2016 before a sharp decline since 2017. The proportion of patients with measure of

6 BMI was stable over time.

8 In the DRC, (Figure S3), trends in reported measures for BMI and WHO staging at enrollment in HIV care was available for nearly all patients except in 2014 when measures were available for about $84 \%$ of

10 patients. Measures of CD4 cell count was available for at least $80 \%$ of patients until the year 2013 when

11 there was a sharp decline that culminated in less than $1 \%$ of patients with measures of CD4 reported 12 since 2017 when CD4 measures were no longer needed to determine eligibility for ART after 2016. In

13 ROC (Figure S4) availability of measures of CD4, WHO stage and BMI rose between 2004 and 2007. From

142008 the proportion of patients with these measures continued to fluctuate. Trends in the availability of

15 data for these measures tended upward since 2014 peaking at $83 \%$ for measures of BMI and CD4 and $1645 \%$ for WHO stage.

18 Similar trends were observed in Rwanda (Figure S5) where the proportion of patients with measures of

19 CD4 cell count and WHO stage remained high (i.e. >70\%) and stable over time before a downward slope

20 since 2016. The most significant decrease relates to the measure of CD4, which decreased to about one

21 third of the patients in the year 2017 and beyond, which coincided with the implementation of the Treat

22 All guidelines. Unlike measures of CD4 and WHO stage, measures of BMI, overall was available for less

23 than $50 \%$ of patients, but rose steadily through the years, peaking at $80 \%$ in 2017 .

Characteristics of patients initiating ART within 30 days of enrolling in HIV care in the current in CA-IeDEA clinic

27 The characteristics of patients who first initiated ART within 30 days of enrollment in care at the

28 participating clinic are shown in table 2. Overall, 29,342 participants were initiated on ART within 30

29 days of their enrollment of whom $66 \%$ were women. Median age among this first time ART initiators

30 when they enrolled in care at the participating site was 35 years (IQR:29,43). Women were slightly

31 younger than men (34 years vs 39 years) $(p=<.0 .001)$. Median CD4 among this first time ART initiators

32 within 30 days of enrollment was was 203 cell/uL (IQR: 100,340). Median CD4 cell count at ART initiation 
medRxiv preprint doi: https://doi.org/10.1101/2020.07.17.20156141; this version posted July 17, 2020. The copyright holder for this preprint (which was not certified by peer review) is the author/funder, who has granted medRxiv a license to display the preprint in perpetuity.

All rights reserved. No reuse allowed without permission.

1 was higher among women (216 cell/uL; IQR: 109, 356) than men (182 cell/uL; IQR: 82,309), $p=<0.001$.

2 About $44 \%$ of first time ART initiators did so in the year 2015 and beyond. Overall, 36\% and $20 \%$ of first

3 time ART initiators were missing CD4 cell count and WHO staging measures.

4

5 Table 2: Characteristics of patients initiating ART use within 30 days of enrollment into HIV care at

6 participating CA-leDEA clinic

\begin{tabular}{|c|c|c|c|c|c|}
\hline Variable & Code & Total & Women & Men & P-value \\
\hline Adult & & 29342 & $19308(65.8)$ & $10034(34.2)$ & \\
\hline Pregnant & & & $1700(8.8)$ & & \\
\hline \multirow[t]{5}{*}{ Age (yrs) median (IRQ) } & Median (IQR) & $35(29,43)$ & $34(28,41)$ & $39(32,45)$ & $<0.001$ \\
\hline & $15-24$ & 3402 (11.6) & $2747(14.2)$ & $655(6.5)$ & $<0.001$ \\
\hline & $25-34$ & $10324(35.2)$ & 7668 (39.7) & $2656(26.5)$ & \\
\hline & $35-44$ & 9654 (32.9) & $5700(29.5)$ & 3954 (39.4) & \\
\hline & $45+$ & $5962(20.3)$ & $3193(16.5)$ & 2769 (27.6) & \\
\hline \multirow[t]{6}{*}{ Point of entry into care } & РMTCT & $2748(9.4)$ & $2479(12.8)$ & $269(2.7)$ & $<0.001$ \\
\hline & TB & $7(0.0)$ & $4(0.0)$ & $3(0.0)$ & \\
\hline & VCT & 7219 (24.6) & $3908(20.2)$ & 3311 (33.0) & \\
\hline & Inpatient & $434(1.5)$ & $209(1.1)$ & $225(2.2)$ & \\
\hline & Other & $2342(8.0)$ & $1430(7.4)$ & $912(9.1)$ & \\
\hline & Unknown & $16592(56.5)$ & $11278(58.4)$ & $5314(53.0)$ & \\
\hline \multirow[t]{6}{*}{ Marital status } & Single & $8427(28.7)$ & $5710(29.6)$ & $2717(27.1)$ & $<0.001$ \\
\hline & Married/in union & $9388(32.0)$ & $5251(27.2)$ & $4137(41.2)$ & \\
\hline & Living with partner & $2145(7.3)$ & $1535(8.0)$ & $610(6.1)$ & \\
\hline & Divorced & $1538(5.2)$ & $1106(5.7)$ & $432(4.3)$ & \\
\hline & Widowed & $2669(9.1)$ & $2273(11.8)$ & $396(3.9)$ & \\
\hline & Unknow/Missing & 5175 (17.6) & $3433(17.8)$ & $1742(17.4)$ & \\
\hline \multirow[t]{2}{*}{ Weight for adults, Kg } & Median (IQR) & $58(50,65)$ & $56(49,65)$ & $60(53,68)$ & $<0.001$ \\
\hline & Missing n (\%) & $6254(21.3)$ & 4224(21.9) & $2030(20.2)$ & \\
\hline \multirow[t]{2}{*}{ Height for adults, $\mathrm{CM}$} & Median (IQR) & $164(158,170)$ & $160(156,165)$ & $170(165,175)$ & $<0.001$ \\
\hline & Missing $\mathrm{n}(\%)$ & $4943(16.8)$ & $3122(16.2)$ & $1821(18.1)$ & \\
\hline \multirow[t]{2}{*}{ BMI } & Median (IQR) & $21.55(19.10,24.34)$ & $21.91(19.27,24.89)$ & $20.96(18.82,23.42)$ & $<0.001$ \\
\hline & Missing $\mathrm{n}(\%)$ & 9905(33.8) & $6500(33.7)$ & $3405(33.9)$ & \\
\hline \multirow[t]{6}{*}{ CD4 count (cells/uL) } & Median (IQR) & $203(100,340)$ & $216(109,356)$ & $182(82,309)$ & $<0.001$ \\
\hline & $<100$ & $4686(16.0)$ & $2863(14.8)$ & $1823(18.2)$ & $<0.001$ \\
\hline & $100-199$ & 4575 (15.6) & $2983(15.4)$ & $1592(15.9)$ & \\
\hline & $200-349$ & 5160 (17.6) & 3457 (17.9) & $1703(17.0)$ & \\
\hline & $>350$ & 4418 (15.1) & 3259 (16.9) & 1159 (11.6) & \\
\hline & Missing & $10503(35.8)$ & 6746 (34.9) & $3757(37.4)$ & \\
\hline \multirow[t]{5}{*}{$\begin{array}{l}\text { WHO Stage at } \\
\text { enrollment }\end{array}$} & Stage I & $9171(31.3)$ & 6160 (31.9) & $3011(30.0)$ & $<0.001$ \\
\hline & Stage II & $6348(21.6)$ & 4184 (21.7) & $2164(21.6)$ & \\
\hline & Stage III & $6021(20.5)$ & $3721(19.3)$ & $2300(22.9)$ & \\
\hline & Stage IV & $1935(6.6)$ & $1180(6.1)$ & $755(7.5)$ & \\
\hline & Missing & $5867(20.0)$ & $4063(21.0)$ & $1804(18.0)$ & \\
\hline \multirow[t]{2}{*}{ Country } & Rwanda & $9091(31.0)$ & $5289(27.4)$ & 3802 (37.9) & $<0.001$ \\
\hline & Burundi & 3900 (13.3) & 2671 (13.8) & $1229(12.2)$ & \\
\hline
\end{tabular}


medRxiv preprint doi: https://doi.org/10.1101/2020.07.17.20156141; this version posted July 17, 2020. The copyright holder for this preprint (which was not certified by peer review) is the author/funder, who has granted medRxiv a license to display the preprint in perpetuity.

All rights reserved. No reuse allowed without permission.

2

\begin{tabular}{|c|c|c|c|c|c|}
\hline & Cameroon & 9371 (31.9) & 6148 (31.8) & $3223(32.1)$ & \\
\hline & DRC & $1046(3.6)$ & $847(4.4)$ & $199(2.0)$ & \\
\hline & ROC & $5934(20.2)$ & $4353(22.5)$ & $1581(15.8)$ & \\
\hline \multirow[t]{4}{*}{ Time Period } & Year $<=2006$ & $3540(12.1)$ & $2343(12.1)$ & 1197 (11.9) & $<0.001$ \\
\hline & Year $2007-2010$ & $5395(18.4)$ & 3643 (18.9) & $1752(17.5)$ & \\
\hline & Year 2011 - 2014 & $7618(26.0)$ & $5432(28.1)$ & $2186(21.8)$ & \\
\hline & Year >= 2015 & $12789(43.6)$ & 7890 (40.9) & $4899(48.8)$ & \\
\hline
\end{tabular}

* from 30 days prior to enrollment to 30 days after enrollment. ${ }^{1}$ By Chi-Square Test

Characteristics of patients already using ART prior to enrollment in HIV care at participating

\section{CA-leDEA clinic}

Table 3 shows the characteristics of 7, 601 patients who were already using ART prior to enrolling in HIV care in the current CA-leDEA clinic. Presumably, these were patients transferring from a previous site where they were already initiated on ART after HIV diagnosis. Women made up about two-thirds (69\%) of patients. Median age among ART experienced users was 36 years (IQR:30,43) and women were younger (35 years, IQR: 29,41$)$ than men (40 years IQR: 33,47$)(p=<0.001)$. Voluntary Counseling and Testing (38\%) and PMTCT (11\%) were the main sources of entry into care for ART experienced patients. ART experienced women had higher median CD4 cell/uL than men $392($ IQR 232,584) than ART experienced men 293 (IQR 160, 454). About 61\% of experienced ART users were initiated on ART prior to 2015. 
medRxiv preprint doi: https://doi.org/10.1101/2020.07.17.20156141; this version posted July 17, 2020. The copyright holder for this preprint (which was not certified by peer review) is the author/funder, who has granted medRxiv a license to display the preprint in perpetuity.

All rights reserved. No reuse allowed without permission.

1 Table 3: Characteristics of patients using ART prior to enrollment in HIV care at participating CA-leDEA

2 clinic

\begin{tabular}{|c|c|c|c|c|c|}
\hline Variable & Code & Total & Women & Men & P-value \\
\hline Adult & & 7601 & $5268(69.3)$ & $2333(30.7)$ & \\
\hline Pregnant & & & $193(3.7)$ & & \\
\hline \multirow[t]{5}{*}{ Age (yrs) median (IRQ) } & Median (IQR) & $36(30,43)$ & $35(29,41)$ & $40(33,47)$ & $<0.001$ \\
\hline & $15-24$ & $750(9.9)$ & $600(11.4)$ & $150(6.4)$ & $<0.001$ \\
\hline & $25-34$ & $2568(33.8)$ & 2029 (38.5) & $539(23.1)$ & \\
\hline & $35-44$ & $2605(34.3)$ & $1736(33.0)$ & $869(37.2)$ & \\
\hline & $45+$ & $1678(22.1)$ & $903(17.1)$ & $775(33.2)$ & \\
\hline \multirow[t]{5}{*}{ Point of entry into care } & РMTCT & $840(11.1)$ & $737(14.0)$ & $103(4.4)$ & $<0.001$ \\
\hline & VCT & $2903(38.2)$ & $1868(35.5)$ & 1035 (44.4) & \\
\hline & Inpatient & $98(1.3)$ & $53(1.0)$ & $45(1.9)$ & \\
\hline & Other & $716(9.4)$ & $502(9.5)$ & $214(9.2)$ & \\
\hline & Unknown & $3044(40.0)$ & $2108(40.0)$ & $936(40.1)$ & \\
\hline \multirow[t]{6}{*}{ Marital status } & Single & $1174(15.4)$ & $836(15.9)$ & $338(14.5)$ & $<0.001$ \\
\hline & Married/in union & $1588(20.9)$ & $898(17.0)$ & $690(29.6)$ & \\
\hline & Living with partner & $374(4.9)$ & $271(5.1)$ & $103(4.4)$ & \\
\hline & Divorced & $339(4.5)$ & $283(5.4)$ & $56(2.4)$ & \\
\hline & Widowed & $650(8.6)$ & $580(11.0)$ & $70(3.0)$ & \\
\hline & Unknow/Missing & $3476(45.7)$ & $2400(45.6)$ & $1076(46.1)$ & \\
\hline \multirow[t]{2}{*}{ Weight for adults, Kg } & Median (IQR) & $59(52,67)$ & $58(51,66)$ & $60(54,67)$ & $<0.001$ \\
\hline & Missing n (\%) & $1228(16.2)$ & $833(15.8)$ & $395(16.9)$ & \\
\hline \multirow[t]{2}{*}{ Height for adults, CM } & Median (IQR) & $162(157,169)$ & $160(155,165)$ & $170(165,175)$ & $<0.001$ \\
\hline & Missing n (\%) & $1311(17.2)$ & $867(16.5)$ & $444(19.0)$ & \\
\hline \multirow[t]{2}{*}{ BMI } & Median (IQR) & $22.22(19.92,24.97)$ & $22.83(20.31,25.71)$ & $21.11(19.27,23.37)$ & $<0.001$ \\
\hline & Missing n (\%) & $2379(31.3)$ & $1603(30.4)$ & $776(33.3)$ & \\
\hline \multirow[t]{6}{*}{ CD4 count (cells/uL) } & Median (IQR) & $361(205,543)$ & $392(232,584)$ & $293(160,454)$ & $<0.001$ \\
\hline & $<100$ & $549(7.2)$ & $323(6.1)$ & $226(9.7)$ & $<0.001$ \\
\hline & $100-199$ & $684(9.0)$ & 414 (7.9) & $270(11.6)$ & \\
\hline & $200-349$ & $1241(16.3)$ & $827(15.7)$ & $414(17.7)$ & \\
\hline & $>350$ & $2653(34.9)$ & $2030(38.5)$ & $623(26.7)$ & \\
\hline & Missing & 2474 ( 32.5$)$ & $1674(31.8)$ & $800(34.3)$ & \\
\hline \multirow[t]{5}{*}{ WHO Stage at enrollment } & Stage I & $2064(27.2)$ & $1508(28.6)$ & $556(23.8)$ & $<0.001$ \\
\hline & Stage II & $1238(16.3)$ & $867(16.5)$ & 371 (15.9) & \\
\hline & Stage III & $1650(21.7)$ & $1104(21.0)$ & $546(23.4)$ & \\
\hline & Stage IV & $465(6.1)$ & $278(5.3)$ & $187(8.0)$ & \\
\hline & Missing & $2184(28.7)$ & $1511(28.7)$ & $673(28.8)$ & \\
\hline \multirow[t]{5}{*}{ Country } & Rwanda & 5159 ( 67.9) & $3492(66.3)$ & $1667(71.5)$ & $<0.001$ \\
\hline & Burundi & $290(3.8)$ & $238(4.5)$ & $52(2.2)$ & \\
\hline & Cameroon & 1849 (24.3) & $1317(25.0)$ & $532(22.8)$ & \\
\hline & DRC & $165(2.2)$ & $121(2.3)$ & $44(1.9)$ & \\
\hline & ROC & $138(1.8)$ & 100 (1.9) & $38(1.6)$ & \\
\hline \multirow[t]{4}{*}{ Time Period } & Year $<=2006$ & 484 (6.4) & $326(6.2)$ & $158(6.8)$ & $<0.001$ \\
\hline & Year $2007-2010$ & $1603(21.1)$ & 1036 (19.7) & $567(24.3)$ & \\
\hline & Year 2011 - 2014 & $2566(33.8)$ & $1854(35.2)$ & $712(30.5)$ & \\
\hline & Year $>=2015$ & $2948(38.8)$ & $2052(39.0)$ & $896(38.4)$ & \\
\hline
\end{tabular}


medRxiv preprint doi: https://doi.org/10.1101/2020.07.17.20156141; this version posted July 17, 2020. The copyright holder for this preprint (which was not certified by peer review) is the author/funder, who has granted medRxiv a license to display the preprint in perpetuity.

All rights reserved. No reuse allowed without permission.

\section{* more than 30 days prior to enrollment $\quad{ }^{1}$ By Chi-Square test}

Trends in measures of CD4 cell count and ART use prior to and after enrollment into care in CA- leDEA

Before the WHO's 2015 Treat All recommendations, CD4 cell count was an important criterion for determining eligibility for ART initiation. While CD4 testing is no longer required for determining eligibility for ART, pre-treatment CD4 testing is still recommended in order to identify patients with advanced disease who are at elevated risk for mortality. We examined trends in median CD4 cell count among all patients enrolling in HIV care at the participating clinics as well as ART use either prior to or after they enrolled in HIV care at the current site.

Among patients at participating CA-leDEA sites, median CD4 cell count for all patients when they enrolled in care increased from 190 cells/uL in the period before 2005 to 334 cells/uL after 2017 (Figure 2). In 2005, the proportion of respondents who were already using ART before they enrolled in HIV care at the current CA-leDEA participating site was less than $2 \%$ increasing to $18 \%$ in 2017 . The proportion of patients who initiated ART within 30 days of enrollment in HIV care at the current CA-IeDEA site grew from $16 \%$ in 2005 to $75 \%$ after 2017.

\section{Fig. 2: Trends in CD4 cell count and ART use before enrollment and after enrollment in HIV care} among PLWH in all participating CA-IeDEA countries

21

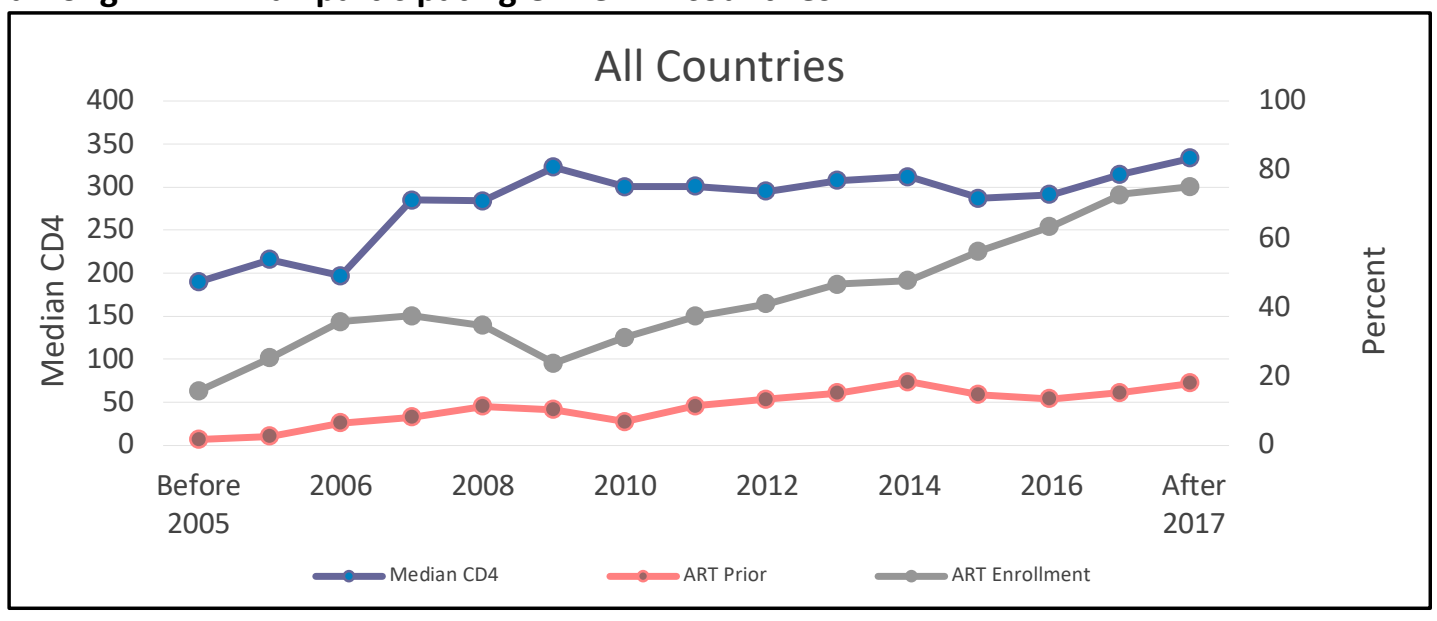

Disaggregated data by country is presented in Supplemental Figures S6-S10. In Burundi (Figure S6), recent median CD4 cell count at enrollment increased from 281 cells /uL in 2009 to 504 cells/uL in 2017 before a sharp decline to 372 cells/uL after 2017. About $5 \%$ of patients enrolling in HIV care at the participating CA-leDEA site were already using ART before enrollment, but among those newly initiating ART, the proportion rose from about 10\% in 2009 to 91\% after 2017. 
medRxiv preprint doi: https://doi.org/10.1101/2020.07.17.20156141; this version posted July 17, 2020. The copyright holder for this preprint (which was not certified by peer review) is the author/funder, who has granted medRxiv a license to display the preprint in perpetuity.

All rights reserved. No reuse allowed without permission.

2 The trend in Cameroon (Figure S7) show median CD4 increase from 155 cells/uL in 2004 to 229 cells/uL 3 in 2017 and falling to 177 cells/uL after 2017. The proportion of patients using ART prior to enrollment 4 into CA-leDEA participating clinic increased from $8 \%$ in 2004 to $22 \%$ in the period after 2017 while the

5 proportion of patients initiating ART the first time when they enrolled in the CA-leDEA participating site 6 increased from 67\% in 2004 to $74 \%$ after 2017.

In the DRC (Figure S8), median CD4 fluctuated from 327 cells/uL in 2005 to 295 cells/uL in 2006 and 375 cells/uL in 2007. Median CD4 cell count was highest in 2017 at 517 cells/uL. Similar fluctuations were observed with regard to ART use either prior to or after enrollment in HIV care at the participating clinic.

In the ROC (Figure S9), median CD 4 cell count among those enrolled in care fell from 221 cells/uL in the 13 period prior to 2005 to as low as 142 cells/uL in 2005 before rising between 2006 and 2010 and then 14 slightly from 2011 until 2015 and from 2016 onwards. Between 2005 and 2009, less than $4 \%$ of patients 15 who enrolled in HIV at the current site were experienced ART users while the proportion of first-time 16 users increased from 4\% in 2005 to $51 \%$ in 2007 and again from 2010 onwards.

18 Trends in Rwanda were similar to those observed in the other countries (Figure S10). Recent median

19 CD4 at enrollment increased in 2005 and then fell in 2006 before rising again and peaking at 457 cells/uL 20 after 2017. The proportion of patients who were experienced ART users prior to enrollment was $2 \%$ in

212005 and $26 \%$ after 2017. The proportion of first time ART initiators increased 32\% in 2005 to $67 \%$ after 222017.

\section{Discussion}

25 In this study describing trends in demographic, clinical and immunological characteristics of the largest

26 cohort of adult PLWH entering care and initiating ART in Central Africa from 2004-2018, we found

27 increases in baseline CD4 cell count among patients enrolling in HIV care in the participating CA-leDEA

28 sites and in the proportion of first time ART users within 30 days of entry into care at participating sites

29 in Burundi, Cameroon, DRC, ROC and Rwanda.

31 These findings shed light on important demographic, clinical and immunological characteristics of 32 patients entering HIV care and those initiating ART, and also highlight the progress and challenges in 
medRxiv preprint doi: https://doi.org/10.1101/2020.07.17.20156141; this version posted July 17, 2020. The copyright holder for this preprint (which was not certified by peer review) is the author/funder, who has granted medRxiv a license to display the preprint in perpetuity.

All rights reserved. No reuse allowed without permission.

early HIV diagnosis, and ART initiation that are critical to the universal goal to eliminate the virus by 2030. More importantly, our findings can inform effective programs and/or policies to improve long term outcomes and quality of life and substantially reduce mortality among PLWH living in Central Africa, particularly in the era of universal ART use. ${ }^{11}$

Women comprised most of patients who enrolled in care and initiated ART within 30 days of enrollment in our CA-leDEA cohort. While other studies ${ }^{12,13}$ reported that HIV prevalence in SSA is higher among women than men, this discrepancy may reflect the fact that women were more likely to be tested for HIV earlier than men because of contacts with antenatal care during pregnancy. ${ }^{13}$ The higher proportion of women represented in the CA-IeDEA cohort may partly reflect disparities in testing, but may also reflect gender disparities and higher risk of transmission in women and perhaps, higher mortality rates in men. ${ }^{14}$

Before the WHO's 2015 recommendation of universal HIV treatment for all PLWH, also known as "Treat All", CD4 cell count, and WHO staging were the most commonly used criteria for determining treatment eligibility. ${ }^{15}$ Our findings suggest that at that time information on CD4 cell count and WHO staging was missing for a substantial proportion of patients, with likely implications for delayed timing of ART initiation. While there were differences between countries and between women and men, the low median CD4 cell counts at entry into care in the participating CA-leDEA site suggests that PLWH were being diagnosed late and that they were likely entering care with advanced disease, particularly in the pre-Treat All era. In the post Treat All era, rising median CD4 cell counts suggests that patients were entering HIV care earlier, although it is worth highlighting that even after CD4 eligibility thresholds were eliminated, median CD4 cell count at entry into care remained less than 500 cells/uL. We also observed sex differences across countries with women having higher CD4 cell count at enrollment into HIV care at the participating CA-leDEA site and ART initiation than men, perhaps reflecting women's earlier access to HIV testing and diagnosis through antenatal care in PMTCT clinics.

Additionally, the fact that median CD4 count was quite low in the pre-treat all era suggests that patients may not have been accessing treatment early enough and may have been severely immunecompromised by the time treatment is initiated. Analysis of median CD4 count by country shows that patients in Rwanda had the highest median CD4 cell count when they enrolled in care in our participating clinics, which is higher than patients in Burundi, Cameroon, DR Congo and ROC. 
medRxiv preprint doi: https://doi.org/10.1101/2020.07.17.20156141; this version posted July 17, 2020. The copyright holder for this preprint (which was not certified by peer review) is the author/funder, who has granted medRxiv a license to display the preprint in perpetuity.

All rights reserved. No reuse allowed without permission.

1 Over the time period focused on in this study, there were changes in recommended criteria for ART

2 initiation among PLWH, especially more recently, the Treat All guidelines that recommended immediate

3 ART initiation upon HIV diagnosis regardless of clinical and immunological parameters. ${ }^{16}$ Arguably,

4 changes in treatment guidelines may have contributed to the increased proportion of those initiating

5 immediate ART use after entry into care at the participating clinics. Our finding show that ART initiation

6 increased dramatically for PLWH enrolled from 2015 onwards, coinciding with the

7 existence/implementation of the Treat All guidelines.

HIV Voluntary counseling and testing (HIV-VCT) is an important gateway to knowing one's HIV status.

10 VCT is beneficial for the individual by ensuring they know their HIV status and are able to take

11 preventive actions against HIV acquisition or transmission to others. Additionally, knowledge of HIV

12 seropositive status increases the likelihood of early engagement in care, facilitates timely ART initiation

13 and confer protective benefits on the entire population. ${ }^{17}$ Consistent with evidence from other studies ${ }^{18}$,

14 we found VCT clinics as an important route of entry into HIV care for a large proportion of patients in

15 our cohort and this may have contributed to the rapid initiation of ART within 30 days of enrollment.

17 This descriptive study utilized data from 5 countries to describe the demographic, clinical and

18 immunological characteristics of PLWH in Burundi, Cameroon, Democratic Republic of Congo, Republic

19 of Congo and Rwanda. This combined data set that examined trends in demographic, clinical and

20 immunological characteristics over a 14-year period in the largest cohort of adult PLWH entering care

21 and initiating ART in Central Africa is a strength of the study. Nonetheless, there are limitations, which

22 warrant caution in interpretation of the findings reported here. First, we highlight the different sample

23 sizes of the cohort in each participating country. That nearly 4 in 10 CA-leDEA patients were from

24 Rwanda may have skewed the results described here. Second, missing data on weight, height, CD4 cell

25 count and WHO staging in many clinics impacted the findings reported in this study. Additionally, the

26 potential non-representativeness of the selected clinics and their concentration in largely urban and

27 peri-urban settings is another limitation as clinics in urban and semi-urban settings do not necessarily

28 represent all health facilities, especially those in rural settings providing HIV care in all countries. In

29 addition, the participating clinics may be better resourced to scale up patient enrollment in care and

30 treatment initiation, which may not reflect the disparity between urban/peri-urban and rural health

31 facilities. 
medRxiv preprint doi: https://doi.org/10.1101/2020.07.17.20156141; this version posted July 17, 2020. The copyright holder for this preprint (which was not certified by peer review) is the author/funder, who has granted medRxiv a license to display the preprint in perpetuity.

All rights reserved. No reuse allowed without permission.

1 Despite these limitations, the CA-leDEA as a cohort study offers an opportunity for further longitudinal

2 analysis of the socio-contextual and health system factors that facilitate or hinder timely HIV diagnosis,

3 enrollment in care, ART initiation among PLWH in the region. This is critical because Central Africa

4 continues to lag behind other regions in curtailing the spread of HIV. For example, in-depth analyses are

5 needed to examine trends in long-term outcomes among PLWH in this region so as to generate evidence

6 to inform programs and policies that addresses the circumstances that are unique to each country and

7 the region.

\section{Conclusion}

10 Trends in demographic, clinical and immunological characteristics of patients entering into HIV care and

11 subsequently initiating ART in the participating sites in Burundi, Cameroon, DRC, ROC and Rwanda

12 highlight improvements over time among those accessing care in this cohort. Although progress is being

13 made especially with improvements in CD4 cell count and the number of patients initiating ART soon

14 after enrolling in care, gaps still remain with scaling up access to care for PLWH who may not be

15 accessing care. Thus, implementing contextually relevant program and policy strategies to address gaps

16 that remain is critical. 
medRxiv preprint doi: https://doi.org/10.1101/2020.07.17.20156141; this version posted July 17, 2020. The copyright holder for this preprint (which was not certified by peer review) is the author/funder, who has granted medRxiv a license to display the preprint in perpetuity.

All rights reserved. No reuse allowed without permission.

\section{References}

1. Joint United Nations Program on AIDS: Global HIV/AIDS Statistics 2019 Fact Sheet. Available at https://www.unaids.org/en/resources/fact-sheet

2. World Health Organization. Consolidated guidelines on the use of Antiretroviral Therapy drugs for treating and preventing HIV infection. Recommendations for a public health approach. Second Edition June 2016. Available at https://www.who.int/hiv/pub/arv/arv-2016/en/

3. Joint United Nations Program on AIDS. West and Central Africa Regional Report. Available at https://www.unaids.org/en/regionscountries/westandcentralafrica

4. Joint United Nations Program on AIDS: $90-90-90$ Treatment for All. Available at https://www.unaids.org/en/resources/909090

5. Joint United Nations Program on AIDS. UNAIDS Data 2018. Available at https://www.unaids.org/sites/default/files/media asset/unaids-data-2018 en.pdf

6. Joint United Nations Program on AIDS. The Western and Central Africa catch up plan: Putting HIV Treatment on the fast track by 2018. Available at https://www.unaids.org/sites/default/files/media_asset/WCA-catch-up-plan_en.pdf

7. Joint United Nations Program on AIDS. Ending AIDS: Progress toward the 90-90-90 targets. Available at https://www.unaids.org/en/resources/documents/2017/20170720 Global AIDS update 2017

8. Kharsany AB, Karim QA. HIV Infection and AIDS in Sub-Saharan Africa: Current Status, Challenges and Opportunities. Open AIDS J. 2016;10:34-48. Published 2016 Apr 8.

doi:10.2174/1874613601610010034

9. Egger M, Ekouevi DK, Williams C, et al. Cohort Profile: the international epidemiological databases to evaluate AIDS (IeDEA) in sub-Saharan Africa. Int J Epidemiol. 2012;41(5):12561264. doi:10.1093/ije/dyr080

10. Project RedCap. Available at https://projectredcap.org/about/

11. Gakhar H, Kamali A, Holodniy M. Health-related quality of life assessment after antiretroviral therapy: a review of the literature. Drugs. 2013;73(7):651-672. doi:10.1007/s40265-013-0040-4

12. Hegdahl HK, Fylkesnes KM, Sandøy IF. Sex Differences in HIV Prevalence Persist over Time: Evidence from 18 Countries in Sub-Saharan Africa. PLoS One. 2016;11(2):e0148502. Published 2016 Feb 3. doi:10.1371/journal.pone.0148502

13. Sharma M, Barnabas RV, Celum C. Community-based strategies to strengthen men's engagement in the HIV care cascade in sub-Saharan Africa. PLoS Med. 2017;14(4):e1002262. Published 2017 Apr 11. doi:10.1371/journal.pmed.1002262 
medRxiv preprint doi: https://doi.org/10.1101/2020.07.17.20156141; this version posted July 17, 2020. The copyright holder for this preprint (which was not certified by peer review) is the author/funder, who has granted medRxiv a license to display the preprint in perpetuity. All rights reserved. No reuse allowed without permission.

14. Hegdahl HK, Fylkesnes KM, Sandøy IF. Sex Differences in HIV Prevalence Persist over Time: Evidence from 18 Countries in Sub-Saharan Africa. PLoS One. 2016;11(2):e0148502. Published 2016 Feb 3. doi:10.1371/journal.pone.0148502

15. Ford N, Meintjes G, Vitoria M, Greene G, Chiller T. The evolving role of CD4 cell counts in HIV care. Curr Opin HIV AIDS. 2017;12(2):123-128. doi:10.1097/COH.0000000000000348

16. World Health Organization. Treat all policy adoption and implementation in all countries. Available at https://www.who.int/hiv/pub/arv/treat-all-uptake/en/

17. World Health Organization. Scaling up HIV testing and counseling services. A toolkit for managers. Available at https://www.who.int/hiv/pub/vct/counsellingtestingtoolkit.pdf

18. Fonner VA, Denison J, Kennedy CE, O'Reilly K, Sweat M. Voluntary counseling and testing (VCT) for changing HIV-related risk behavior in developing countries. Cochrane Database Syst Rev. 2012;9(9):CD001224. Published 2012 Sep 12. doi:10.1002/14651858.CD001224.pub4 
medRxiv preprint doi: https://doi.org/10.1101/2020.07.17.20156141; this version posted July 17 , 2020. The copyright holder for this preprint (which was not certified by peer review) is the author/funder, who has granted medRxiv a license to display the preprint in perpetuity.

All rights reserved. No reuse allowed without permission.

\section{Funding acknowledgement}

Research reported in this publication was supported by the National Institutes of Health's National Institute of Allergy and Infectious Diseases (NIAID), the Eunice Kennedy Shriver National Institute of Child Health \& Human Development (NICHD), the National Cancer Institute (NCI), the National Institute on Drug Abuse (NIDA), the National Heart, Lung, and Blood Institute (NHLBI), the National Institute on Alcohol Abuse and Alcoholism (NIAAA), the National Institute of Diabetes and Digestive and Kidney Diseases (NIDDK), the Fogarty International Center (FIC), the National Library of Medicine (NLM), and the Office of the Director (OD) under Award Number U01AI096299 (Central Africa-leDEA). The content is solely the responsibility of the authors and does not necessarily represent the official views of the National Institutes of Health.

\section{Acknowledgements list}

Site investigators and cohorts:

Nimbona Pélagie, Association Nationale de Soutien aux Séropositifs et Malade du Sida (ANSS), Burundi; Patrick Gateretse, Jeanine Munezero, Valentin Nitereka, Théodore Niyongabo, Christelle Twizere, Centre National de Reference en Matière de VIH/SIDA, Burundi; Hélène Bukuru, Thierry Nahimana, Centre Hospitalo-Universitaire de Kamenge (CHUK), Burundi; Elysée Baransaka, Patrice Barasukana, Eugene Kabanda, Martin Manirakiza, François Ndikumwenayo, CHUK/Burundi National University, Burundi; Jérémie Biziragusenyuka, Ange Marie Michelline Munezero, Hospital Prince Régent Charles (HPRC), Burundi; Tabeyang Mbuh, Kinge Thompson Njie, Edmond Tchassem, Kien-Atsu Tsi, Bamenda Hospital, Cameroon; Rogers Ajeh, Mark Benwi, Marc Lionel Ngamani, Victorine Nkome, Falone Sandjong, Clinical Research Education and Consultancy (CRENC), Cameroon; Anastase Dzudie, CRENC and Douala General Hospital, Cameroon; Akindeh Mbuh, CRENC and University of Yaoundé, Cameroon; Djenabou Amadou, Amadou Dodo Balkissou, Eric Ngassam, Eric Walter Pefura Yone, Jamot Hospital, Cameroon; Alice Ndelle Ewanoge, Norbert Fuhngwa, Ernestine Kendowo, Chris Moki, Denis Nsame Nforniwe, Limbe Regional Hospital, Cameroon; Catherine Akele, Faustin Kitetele, Patricia Lelo, Martine Tabala, Kalembelembe Pediatric Hospital, Democratic Republic of Congo; Emile Wemakoy Okitolonda, Cherubin Ekembe, Kinshasa School of Public Health, Democratic Republic of Congo; Merlin Diafouka, Martin Herbas Ekat, Dominique Mahambou Nsonde, CTA Brazzaville, Republic of Congo; Adolphe Mafou, CTA Pointe-Noire, Republic of Congo; Nicole Ayinkamiye, Jules Igirimbabazi, Bethsaida Health Center, Rwanda; Emmanuel Ndamijimana, Providance Uwineza, Busanza Health Center, Rwanda; Emmanuel Habarurema, Marie Luise Nyiraneza, Gahanga Health Center, Rwanda; Dorothee Mukamusana, Liliane Tuyisenge, Gikondo Health Center, Rwanda; Catherine Kankindi, Christian Shyaka, Kabuga Health Center, Rwanda; Marie Grace Ingabire, Bonheur Uwakijijwe, Kicukiro Health Center, Rwanda; Jules Ndumuhire, Marie Goretti Nyirabahutu, Masaka Health Center, Rwanda; Yvette Ndoli, Oliver Uwamahoro, Nyarugunga Health Center, Rwanda; Ribakare Muhayimpundu, Sabin Nsanzimana, Eric Remera, Esperance Umumararungu, Rwanda Biomedical Center, Rwanda; Lydia Busingye, Alex M Butera, Josephine Gasana, Thierry Habiryayo, Charles Ingabire, Jules Kabahizi, Jean Chrysostome Kagimbana, Faustin Kanyabwisha, Gallican Kubwimana, Benjamin Muhoza, Athanase Munyaneza, Gad Murenzi, Francoise Musabyimana, Francine Mwiza, Gallican Nshogoza Rwibasira, Jean d'Amour Sinayobye, Patrick Tuyisenge, Rwanda Military Hospital, Rwanda; Chantal Benekigeri, Jacqueline Musaninyange, WE-ACTx Health Center, Rwanda.

\section{Coordinating and Data Centers:}

Adebola Adedimeji, Kathryn Anastos, Madeline Dilorenzo, Lynn Murchison, Jonathan Ross, Marcel Yotebieng, Albert Einstein College of Medicine, USA; Diane Addison, Ellen Brazier, Heidi Jones, Elizabeth Kelvin, Sarah Kulkarni, Denis Nash, Matthew Romo, Olga Tymejczyk, Institute for Implementation Science in Population Health, Graduate School of Public Health and Health Policy, City University of New 
medRxiv preprint doi: https://doi.org/10.1101/2020.07.17.20156141; this version posted July 17, 2020. The copyright holder for this preprint (which was not certified by peer review) is the author/funder, who has granted medRxiv a license to display the preprint in perpetuity. All rights reserved. No reuse allowed without permission.

1 York (CUNY), USA; Batya Elul, Columbia University, USA; Xiatao Cai, Allan Dong, Don Hoover, Hae-Young 2 Kim, Chunshan Li, Qiuhu Shi, Data Solutions, USA; Robert Agler, Kathryn Lancaster, The Ohio State 3 University, USA; Mark Kuniholm, University at Albany, State University of New York, USA; Andrew 4 Edmonds, Angela Parcesepe, Jess Edwards, University of North Carolina at Chapel Hill, USA; Olivia Keiser, 5 University of Geneva; Stephany Duda; Vanderbilt University School of Medicine, USA; April Kimmel, 6 Virginia Commonwealth University School of Medicine, USA. 
medRxiv preprint doi: https://doi.org/10.1101/2020.07.17.20156141; this version posted July 17, 2020. The copyright holder for this preprint (which was not certified by peer review) is the author/funder, who has granted medRxiv a license to display the preprint in perpetuity.

1

2

3

4

5

7

8

9

10

11

12

13

14

15

16

17

\section{Supplementary Materials}

Figure. S1: Trends in proportions having a recent measure for BMI, CD4 cell count and WHO stage in the Burundi CA-leDEA cohort

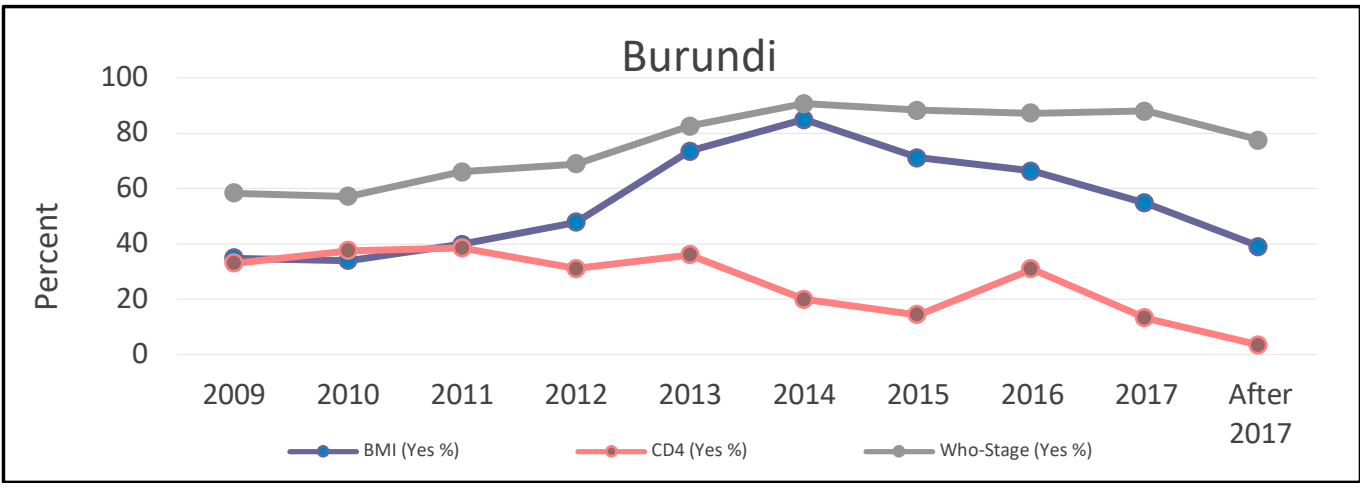

Figure. S2: Trends in proportions having a recent measure for BMI, CD4 cell count and WHO stage in the Cameroon CA-IeDEA cohort

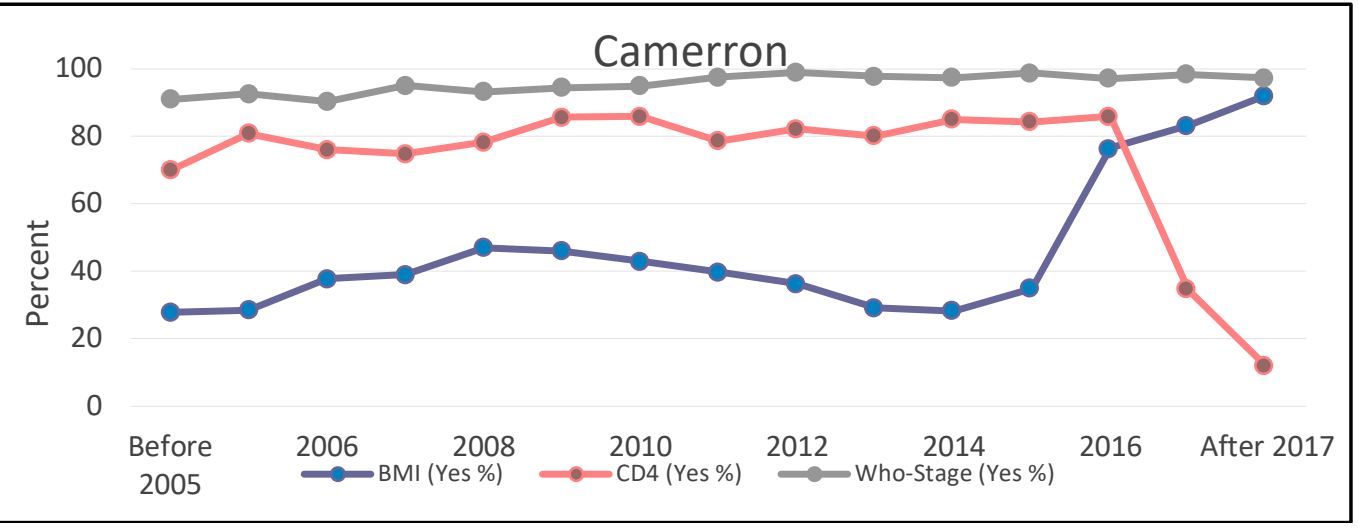

Figure S3: Trends in proportions having a recent measure for BMI, CD4 cell count and WHO stage in the DRC CA-leDEA cohort

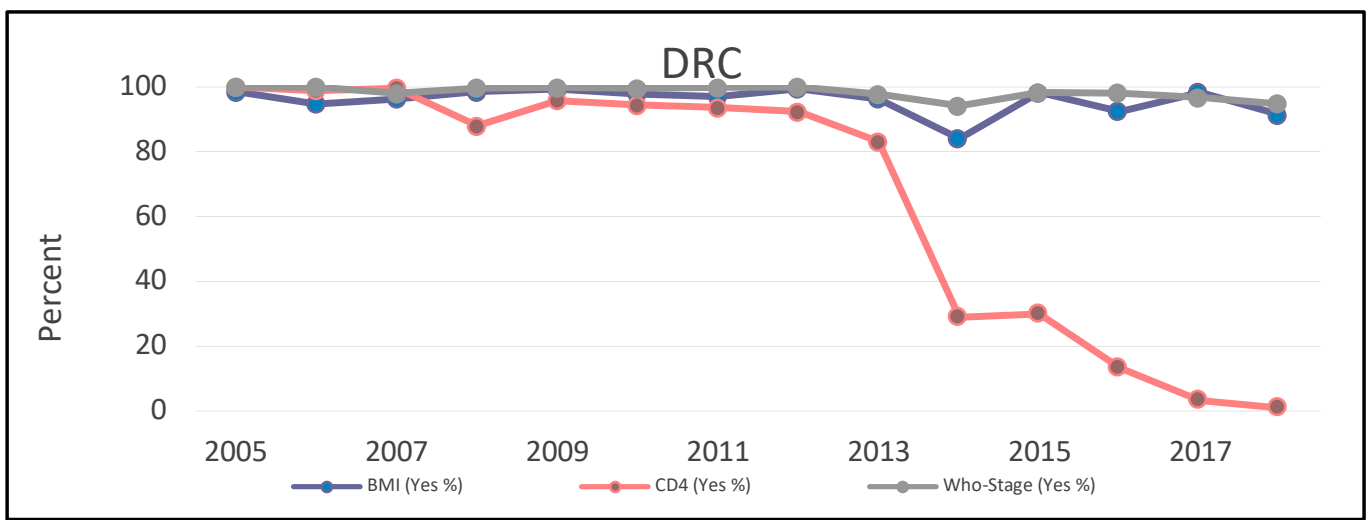


medRxiv preprint doi: https://doi.org/10.1101/2020.07.17.20156141; this version posted July 17, 2020. The copyright holder for this preprint (which was not certified by peer review) is the author/funder, who has granted medRxiv a license to display the preprint in perpetuity.

1 Fig. S4: Trends in proportions having a recent measure for BMI, CD4 cell count and WHO stage in the

2 ROC CA-leDEA cohort

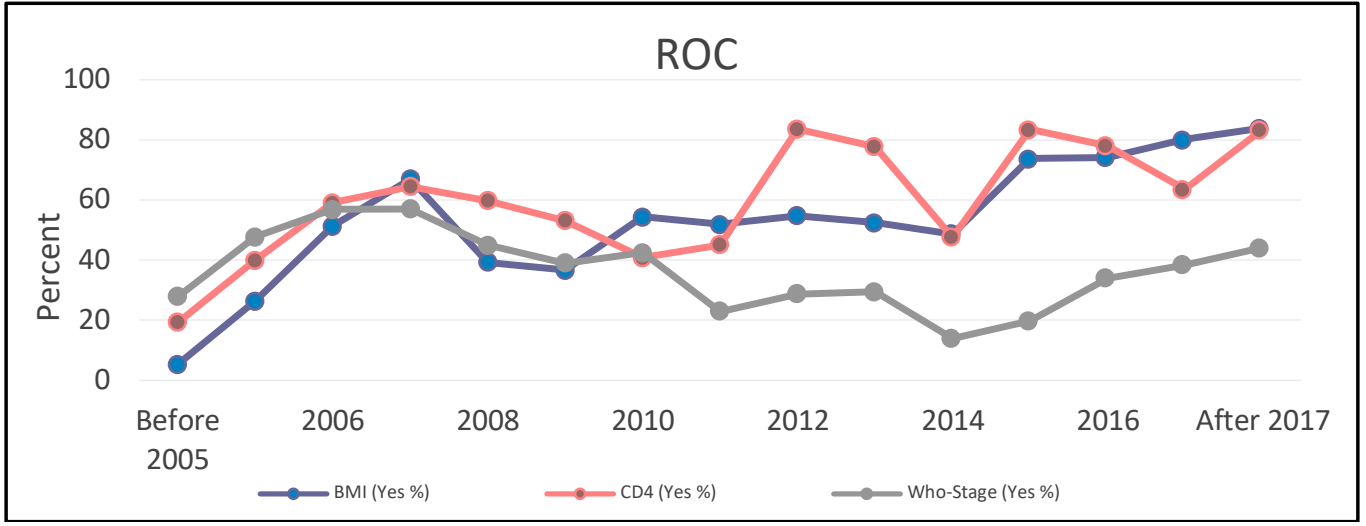

Fig. S5: Trends in having a recent measure for BMI, CD4 cell count and WHO stage at enrollment in HIV care in the Rwanda CA-leDEA cohort

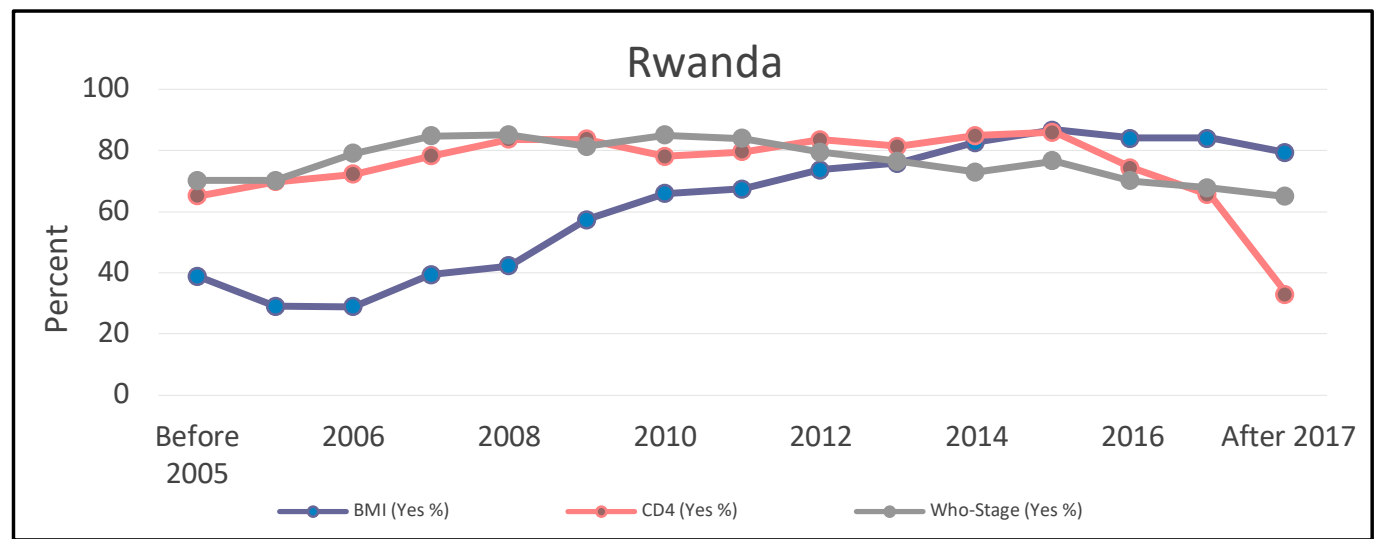

8

Fig. S6: Trends in CD4 cell count and ART use before enrollment and after enrollment in HIV care among PLWH in Burundi CA-leDEA cohort

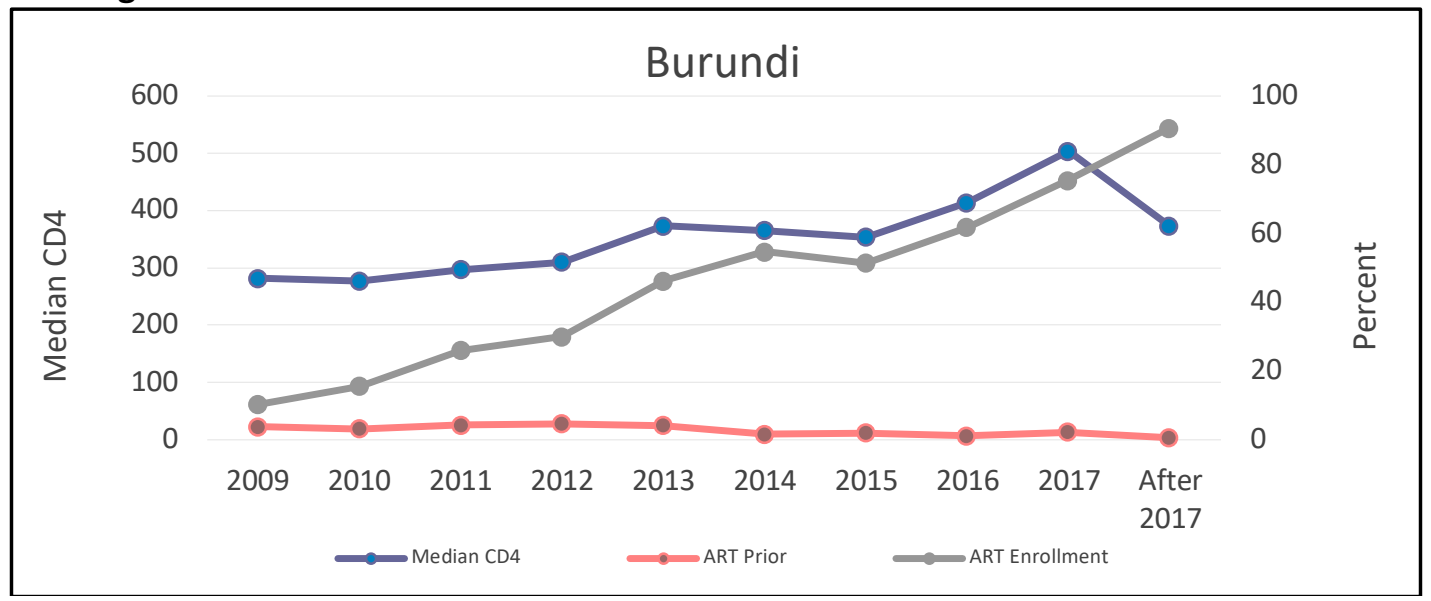

13

14

15

Fig. S7: Trends in CD4 cell count and ART use before enrollment and after enrollment in HIV care among PLWH in Cameroon CA-leDEA cohort 
medRxiv preprint doi: https://doi.org/10.1101/2020.07.17.20156141; this version posted July 17, 2020. The copyright holder for this preprint (which was not certified by peer review) is the author/funder, who has granted medRxiv a license to display the preprint in perpetuity.

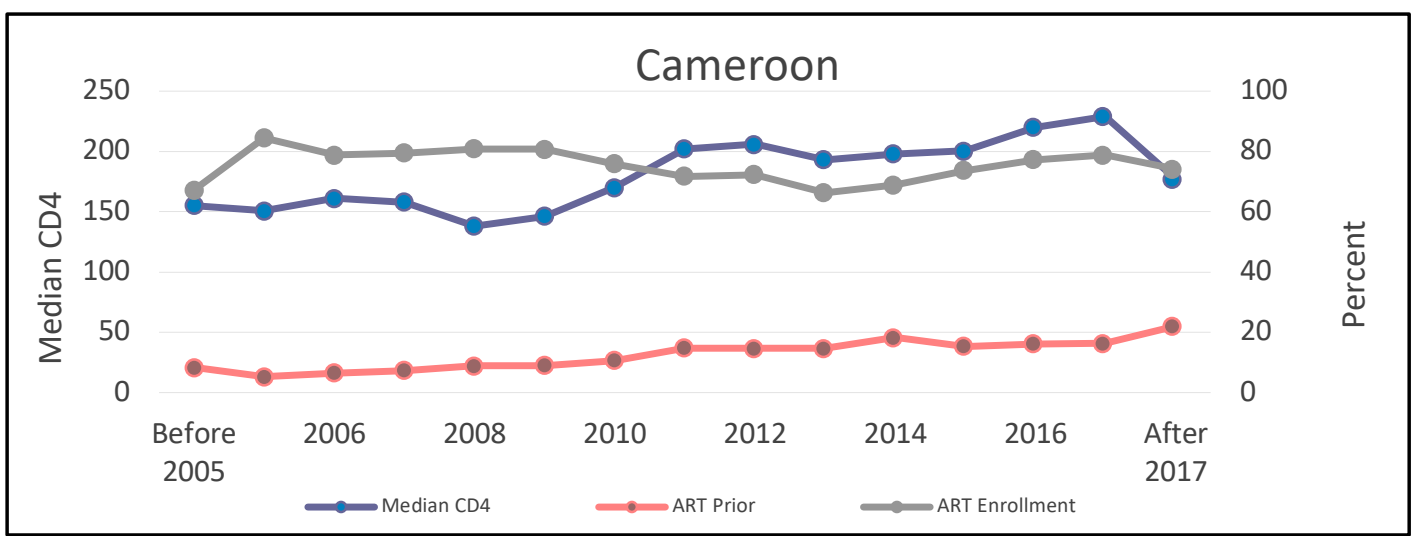

Fig. S8: Trends in CD4 cell count and ART use before enrollment and after enrollment in HIV care among PLWH in DRC CA-leDEA cohort

6

7

8

9

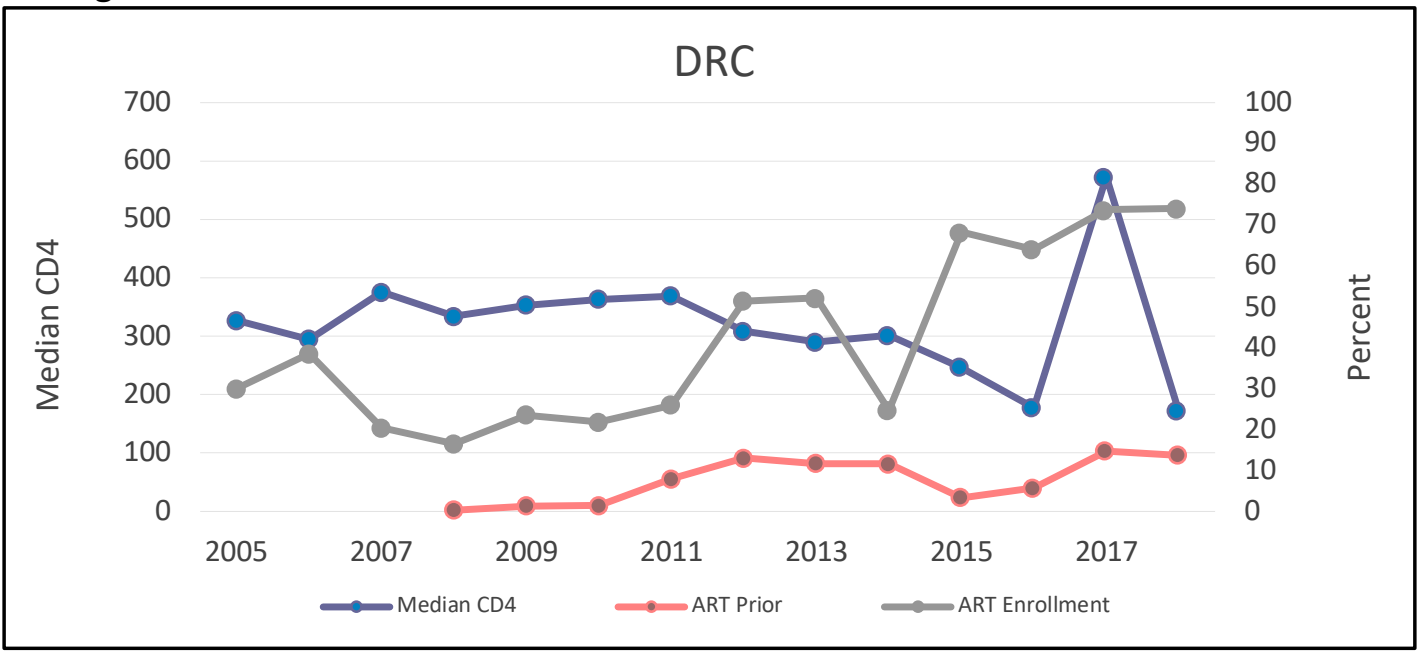

Fig. S9: Trends in CD4 cell count and ART use before enrollment and after enrollment in HIV care among PLWH in ROC CA-leDEA cohort

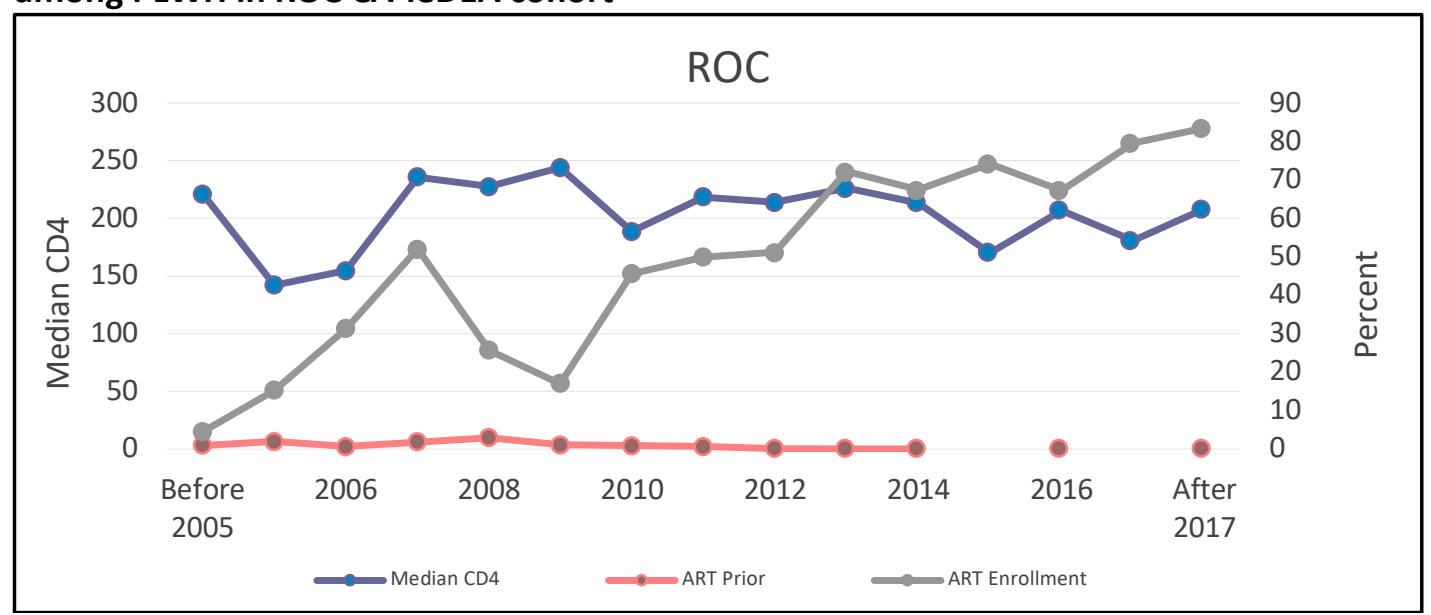

10

11

12 
medRxiv preprint doi: https://doi.org/10.1101/2020.07.17.20156141; this version posted July 17, 2020. The copyright holder for this preprint (which was not certified by peer review) is the author/funder, who has granted medRxiv a license to display the preprint in perpetuity.

All rights reserved. No reuse allowed without permission.

1 Fig. S10: Trends in CD4 cell count and ART use before enrollment and after enrollment in HIV care

2 among PLWH in Rwanda CA-leDEA cohort

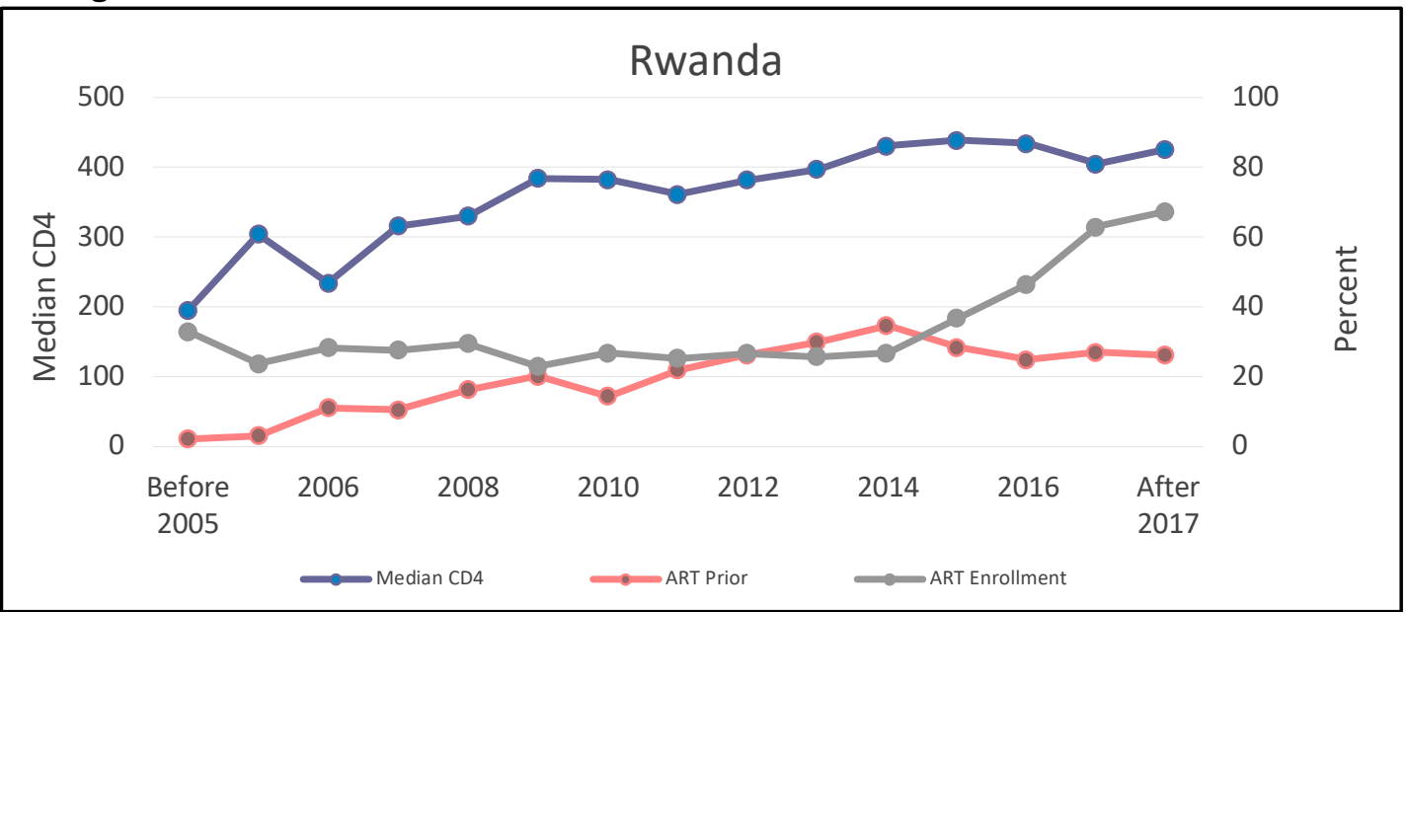

